\title{
PATTERN OF DISTRIBUTION AND ENVIRONMENTAL INFLUENCES ON THE SCIENIDAE COMMUNITY OF THE SOUTHEASTERN BRAZILIAN COAST
}

\author{
Thassya Christina dos Santos Schmidt* and June Ferraz Dias \\ Instituto Oceanográfico da Universidade de São Paulo \\ (Praça do Oceanográfico, 191, 05508-120 São Paulo, SP, Brasil) \\ *Corresponding author: tcsschmidt@gmail.com
}

\begin{abstract}
A B S T R ACT
The Sciaenids have among the highest species richness, numerical abundance and biomass of any family of fishes along the Brazilian coast. The aim of this study was to analyze the composition and spatial and temporal distribution of as well as the influence of temperature, salinity and depth on the sciaenid assemblage of Santos Bay. A total of 29,306 individuals belonging to 13 genera and 21 species were captured, between November 2004 and December 2005, with Stellifer rastrifer representing $70.4 \%$ of the total composition. Highest abundance and biomass occurred on the east side of the bay, and the highest species richness occurred near the mouth of the Santos Channel, which was also the site with least similarity to the other sites. Highest abundances occurred in April 2005 and lowest in September 2005. Key environmental factors influencing distribution of sciaenids were depth and temperature.
\end{abstract}

\section{RESUMO}

A família Sciaenidae apresenta elevada riqueza, abundância numérica e biomassa entre as famílias de peixe do litoral brasileiro. O objetivo deste estudo foi analisar a composição, distribuição espacial e temporal bem como a influência da temperatura, salinidade e profundidade na comunidade de Scienídeos da baía de Santos. Um total de 29.306 indivíduos pertencentes a 13 gêneros e 21 espécies foram capturados, entre novembro de 2004 e dezembro de 2005, com Stellifer rastrifer representando $70,4 \%$ da composição total. Os maiores valores de abundância e biomassa ocorreram no lado leste da baía, e o número de espécies mais elevado foi registrado para a área próxima do canal de Santos. Esta estação também apresentou a menor similaridade com as outras áreas amostradas. Temporalmente em abril de 2005 foi registrada a maior abundância e em setembro de 2005 a menor. Os fatores ambientais que mais influenciaram a distribuição dos Scienídeos foram à profundidade e a temperatura.

Descriptors: Sciaenid community, Abundance, Spatial and temporal distribution, Santos Bay.

Descritores: Comunidade de Sciaenidae, Abundância, Distribuição espaço-temporal, Baía de Santos.

\section{INTRODUCTION}

The family Sciaenidae, also known as croakers, comprises $\sim 70$ genera with 270 species (NELSON, 2006). Approximately 21 genera and 54 species occur along the Brazilian coast, with three genera and 18 species of them being freshwater taxa (MENEZES et al., 2003). Sciaenids are primarily coastal marine fishes, most of them being found inshore over sandy or muddy bottoms, though a few species are found in deep water, and others have adapted to special habitats such as coral reefs (Equetus) and surf zones (Menticirrhus) (MENEZES; FIGUEIREDO, 1980; CHAO, 2002). Many sciaenids use estuarine environments seasonally as nursery grounds during the juvenile phase, and as feeding and growth grounds during the young adult phase, others are year-round inhabitants of estuaries and coastal lagoons (CHAO, 2002).

The Sciaenids represent the main fishery resources in many tropical and temperate areas, besides constituting an important part of the by-catch from fishing targeted at shrimp species, i. e., redspotted shrimp (Farfantepenaeus brasiliensis), Southern white shrimp (Litopenaeus schmitti) and mainly Atlantic sea-bob shrimp (Xiphopenaeus kroyeri) (COELHO et al., 1986; SANTOS et al., 1998; GRAÇA-LOPES et al., 2002; BAIL; BRANCO, 2003; VIANNA et al., 2004; BRANCO; VERANI, 2006; GOMES; CHAVES, 2006). The Sciaenids Stellifer rastrifer, S. brasiliensis, Isopisthus parvipinnis, Paralonchurus brasiliensis represented more than $50 \%$ of the by-catch from shrimp fisheries along the coast of São Paulo state. The high frequency of the 
occurrence of sciaenid in by-catches indicates that these species are abundant where the trawl fishery operates (COELHO et al., 1986). Sciaenids and penaeiod shrimp may co-occur due to similar requirements regarding abiotic factors such as the type of substrate or depth, which will influence both their distribution and prey, since most species live in a close association with the bottom (ARAÚJO et al., 2006) or with related food resources (SOUZA et al., 2008).

Salinity and temperature variations are often assumed to influence spatial and temporal patterns of biological communities in aquatic coastal ecosystems (BLABER; BLABER, 1980; MARSHALL; ELLIOTT, 1998; RAZ-GUZMAN;HUIDOBRO, 2002; SOSA-LÓPEZ et al., 2007; BARLETTA et al., 2008). The aim of this study was to compare the spatial and temporal differences in Sciaenid species assemblages in Santos bay, and to investigate possible environmental influences on sciaenid assemblages.

\section{Material ANd Methods}

Study Area and Sampling Techniques

The Baixada Santista, located on the central coast of São Paulo state, covers the São Vicente and Santos estuarine system, the Santos Bay and the adjacent Continental Shelf (CETESB, 2001). This area is known for its high levels of pollution from industrial, port and urban activities (BRAGA et al., 2000).

The São Vicente and Santos bay-estuarine system is a heterogeneous environment, consisting of many sub-environments, rocky shores, sandy beaches, mangrove swamps and adjacent muddy substrates, resulting in considerable wildlife variety and interdependence between the species, which contributes to the dynamic equilibrium of the environment (MEIRA et al., 1983).

Fish sampling was undertaken monthly in Santos bay between November 2004 and December 2005 (except for December 2004) at six oceanographic stations (Fig. 1). Sampling was performed with an otter trawl, which operated for 10 minutes at a speed of 2 knots. Temperature and salinity data from the entire water column at each oceanographic station were recorded using a Conductivity, Temperature and Depth probe (CTD).

The Sciaenids were identified to species level in accordance with Menezes and Figueiredo (1980) and Chao (2002), with further taxonomic updates based on Menezes et al. (2003). Identification of Macrodon ancylodon and Macrodon autricauda was based on a taxonomic review by Carvalho-Filho et al. (2010). For each fish the total length (TL: nearest $0.1 \mathrm{~mm}$ ) and weight (WT: nearest $0.01 \mathrm{~g}$ ) were measured and recorded.

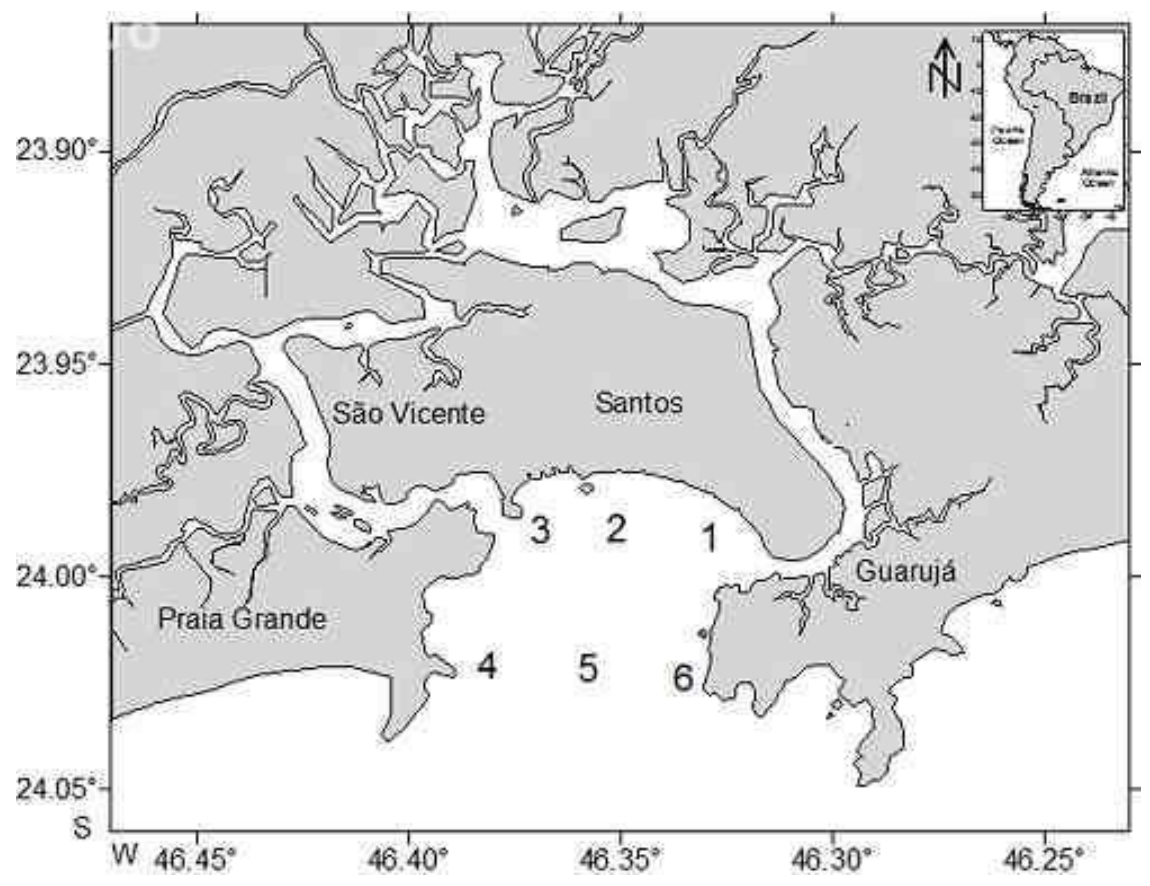

Fig. 1. Map of the oceanographic stations in Santos Bay. 
Analysis

Margalef's richness (R), Pielou's equitability (J), Shannon \& Wiener's ( $\left.\mathrm{H}^{\prime}\right)$ diversity and Simpson's dominance indices were calculated for monthly samples from each station (BEGON et al., 2006). Fish abundance and environmental data were $\log (\mathrm{x}+1)$ transformed prior to ordination using the Bray-Curtis similarity Index and Canonical Correspondence Analysis.

Canonical Correspondence Analysis (CCA) was applied to describe the relationships between the Sciaenid species in the Santos bay in temporal and spatial terms and to identify the most important environmental variables affecting the structure of the sciaenid community. The environmental variables considered in the model were depth, temperature and salinity. The CCA produces a biplot on which environmental variables are represented as arrows (vectors) radiating from the origin of the ordination, i.e., the length of an environmental vector is proportional to the strength of the relationship between the environmental variable that the vector represents and the abundance of the species analyzed
(BARLETTA et al., 2008). Spearman rank correlation coefficients were used to determine the effect of the environmental variables (depth, temperature and salinity) on the abundance of fish species. For all statistical analyses alpha $=0.05$.

\section{RESULTS}

There was great seasonal variation in temperature with a maximum of $26.2^{\circ} \mathrm{C}$ in the summer and autumn months (January to May 2005) and a minimum of $20.4^{\circ} \mathrm{C}$ during the winter (July to September 2005) (Fig. 2). Temperature and salinity presented little spatial variation. The salinity presented its lowest value in October 2005 (30.3) and its highest value in November 2004, with a maximum of 35.3 (Fig. 2).

A total of 29,306 specimens comprising 13 genera and 21 species of Sciaenidae were collected. The genera Stellifer and Cynoscion were and were each represented by four species each. The most abundant species in terms of numerical abundance (70.4\%) and weight was Stellifer rastrifer (Table 1).
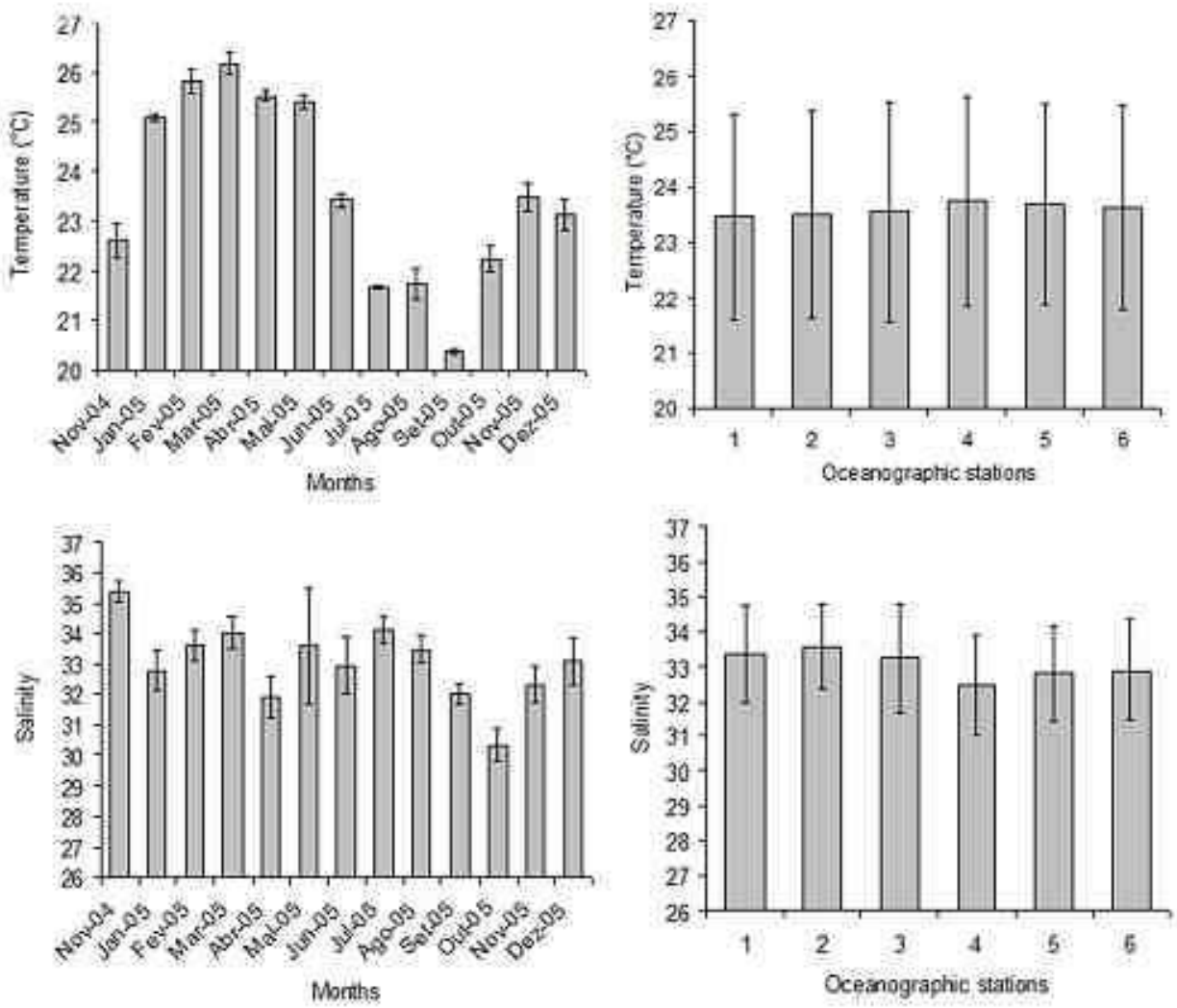

Fig. 2. Temporal and spatial variations in mean $( \pm$ SD) abiotic environmental variables (temperature and salinity) in Santos bay. 
Table 1. Species of Sciaenidae caught in Santos bay with abundance frequency $(\mathrm{N}(\%))$ and biomass frequency (\%). Species codes were used in Figures 3, 7 and 8.

\begin{tabular}{lccc}
\hline \hline \multicolumn{1}{c}{ Species } & Species Code & N $(\%)$ & $\%$ biomass \\
\hline Stellifer rastrifer (Jordan, 1889) & STRA & 70.39 & 60.73 \\
Isopisthus parvipinnis (Cuvier, 1830) & ISPA & 7.66 & 3.34 \\
Stellifer brasiliensis (Schultz, 1945) & STBR & 5.70 & 7.39 \\
Paralonchurus brasiliensis (Steindachner, 1875) & PABR & 5.56 & 9.15 \\
Macrodon atricauda (Günther, 1880) & MAAT & 3.93 & 3.17 \\
Stellifer stelifer (Bloch, 1790) & STST & 2.28 & 1.24 \\
Nebris micropsCuvier, 1830 & NEMI & 1.57 & 4.23 \\
Micropogonias furnieri (Desmarest, 1823) & MIFU & 0.91 & 5.42 \\
Stellifer sp. & STSP & 0.78 & 0.33 \\
Larimus breviceps Cuvier, 1830 & LABR & 0.40 & 1.64 \\
Cynoscion virescens (Cuvier, 1830) & CYVI & 0.25 & 1.65 \\
Menticirrhus americanus (Linnaeus, 1758) & MEAM & 0.19 & 0.86 \\
Bairdiella ronchus (Cuvier, 1830) & BARO & 0.15 & 0.72 \\
Cynoscion jamaicensis (Vaillant \& Bocourt, 1883) & CYJA & 0.12 & $<0.05$ \\
Cynoscion sp. & CYSP & $<0.05$ & $<0.05$ \\
Ophioscion punctatissimus Meek \& Hildebrand, 1925 & OPPU & $<0.05$ & $<0.05$ \\
Umbrina canosai Berg, 1895 & UMCA & $<0.05$ & $<0.05$ \\
Ctenosciaena gracilicirrhus (Metzelaar, 1919) & CTGR & $<0.05$ & $<0.05$ \\
Cynoscion leiarchus (Cuvier, 1830) & CYLE & $<0.05$ & $<0.05$ \\
Umbrina coroides Cuvier, 1830 & UMCO & $<0.05$ & $<0.05$ \\
Menticirrhus littoralis (Holbrook, 1847) & MELI & $<0.05$ & $<0.05$ \\
\hline
\end{tabular}

Cluster analyses of Sciaenid species showed two main groups with $75 \%$ similarity. The first and second groups consisted, respectively, of the least and the most abundant species. The second group was subdivided into two species sub-groups: (i) those species with highest number of individuals caught, i.e., Stellifer rastrifer, Macrodon atricauda, Isopisthus parvipinnis, S. brasiliensis, Paralonchurus brasiliensis, Micropogonias furnieri, Stellifer sp., S. stellifer and Nebris microps, and (ii) those species with intermediate abundance, i.e., Larimus breviceps, Cynoscion jamaicensis, C. virescens, Menticirrhus americanus and Bairdiella ronchus (Fig. 3).

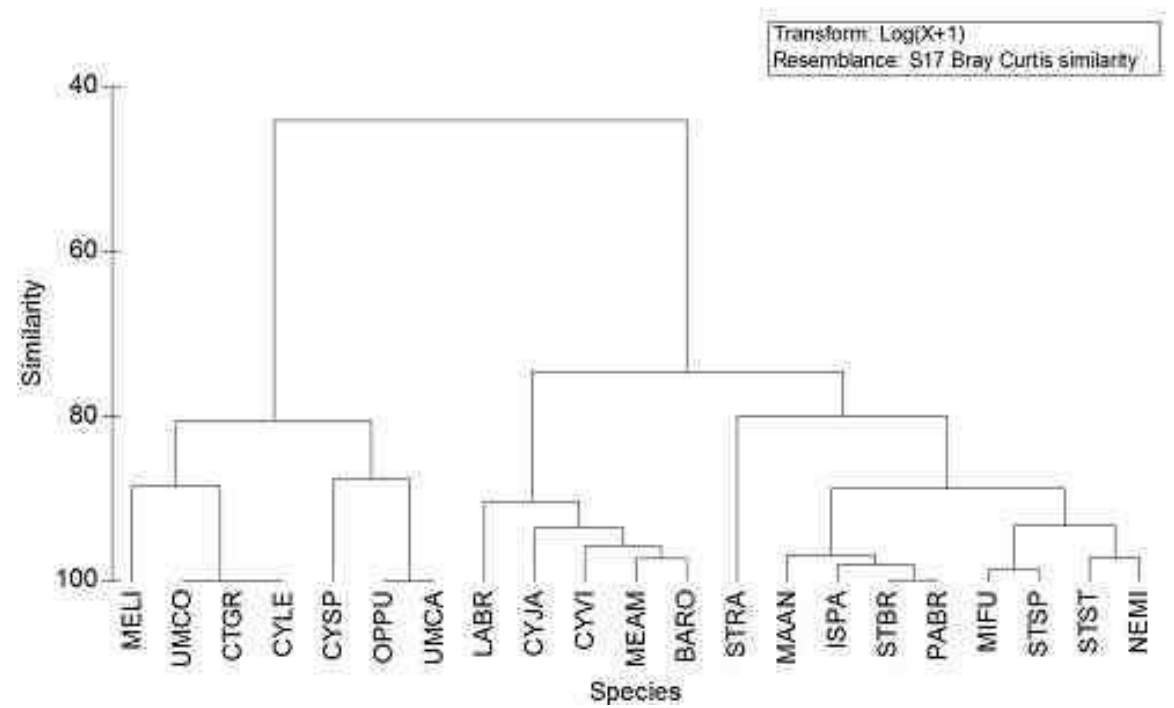

Fig. 3. Cluster diagram of the sciaenid species (numerical abundance) of Santos bay, November 2004 to December 2005. Species codes are given in table 2. 
Differences in species richness, diversity and evenness occurred between the sites. The highest richness, diversity and evenness indices were observed at station 6 (Table 2). The highest numerical abundance was observed at station 1 and the lowest at station 6 . The stations on the western side (stations 3 and 4) showed a similar pattern of abundance (Fig. 4), presenting the lowest values for the Pielou evenness and Shannon \& Wiener Diversity indices, but differing from each other in the Margalef' species richness value (Table 2).

Cluster analyses indicated greater similarity between stations 2 (outer) and 3 (deep) $( \pm 85 \%)$, and between the shallow stations 4 and $5( \pm 88 \%)$. Station 6 had the lowest similarity (70\%) among the stations (Fig. 5), probably because this station also had the lowest abundance (Fig. 4).

Differences in species richness, diversity and evenness also occurred between the months. The highest observed species richness occurred in January 2005 (17 species). The highest diversity occurred in September and December 2005 and the lowest in April 2005 (Table 2). The greatest abundance occurred between April and July, April presenting the highest figure $(\mathrm{N}=5389,18.4 \%)$; September showed the lowest abundance ( $\mathrm{N}=795,2.7 \%)$ (Fig. 4).

Species composition showed $85 \%$ similarity, the highest, between August and November 05, and
$80 \%$ from April to July 05 (autumn and winter). November 2004 was the month with the greatest dissimilarity (Fig. 6).

Canonical correspondence analysis (CCA) of spatial and temporal distribution showed that the species $S$. rastrifer was correlated mainly with the following months: April, May, June and July; $I$. parvipinnis and $P$. brasiliensis with oceanographic stations 1 and 2, and M. atricauda was correlated only with station 2. The species $S$. stellifer showed correlation with April and station 5, while Stellifer sp. correlated with April, June and July 2005 and oceanographic stations 4 and 5. This correlation occurred mainly due to the high abundance in these areas. Bairdiella ronchus and Umbrina canosai showed the highest correlation with station 6 (Fig. 7).

The CCA analysis indicated that the environment variable depth influenced species abundance in Santos bay, with lesser effect from temperature, whereas salinity had no effect. The species Menticirrhus littoralis showed a further correlation with temperature (Fig. 8). No correlation between the abundance of Sciaenid species by month, oceanographic station and any of the environmental variables was found by the Spearman rank correlation.

Table 2. Ecological indices, estimated by month and oceanographic station, of the Sciaenidae in Santos bay.

\begin{tabular}{cccccc}
\hline \hline $\begin{array}{c}\text { Months/ } \\
\begin{array}{c}\text { Oceanographic } \\
\text { stations }\end{array}\end{array}$ & $\begin{array}{c}\text { Species } \\
\text { richness }\end{array}$ & $\begin{array}{c}\text { Margalef's richness } \\
\text { index (D) }\end{array}$ & $\begin{array}{c}\text { Pielou's evenness } \\
\text { index (J') }\end{array}$ & $\begin{array}{c}\text { Shannon- } \\
\text { Wiener's } \\
\text { diversity index } \\
\text { (H') }\end{array}$ & $\begin{array}{c}\text { Simpson's dominance } \\
\text { index }\end{array}$ \\
\hline Nov-04 & 16 & 2.01 & 0.46 & 1.28 & 0.47 \\
Jan-05 & 17 & 2.14 & 0.45 & 1.27 & 0.44 \\
Feb-05 & 12 & 1.58 & 0.53 & 1.32 & 0.42 \\
Mar-05 & 15 & 1.82 & 0.51 & 1.39 & 0.38 \\
Apr-05 & 14 & 1.51 & 0.26 & 0.69 & 0.72 \\
May-05 & 11 & 1.21 & 0.33 & 0.80 & 0.65 \\
Jun-05 & 12 & 1.38 & 0.37 & 0.92 & 0.60 \\
Jul-05 & 12 & 1.33 & 0.35 & 0.86 & 0.65 \\
Aug-05 & 12 & 1.50 & 0.46 & 1.14 & 0.50 \\
Sep-05 & 12 & 1.65 & 0.66 & 1.65 & 0.29 \\
Oct-05 & 11 & 1.38 & 0.58 & 1.40 & 0.42 \\
Nov-05 & 10 & 1.20 & 0.66 & 1.52 & 0.31 \\
Dec-05 & 11 & 1.44 & 0.68 & 1.64 & 0.23 \\
1 & 16 & 1.64 & 0.43 & 1.18 & 0.50 \\
2 & 15 & 1.69 & 0.51 & 1.38 & 0.34 \\
3 & 14 & 1.53 & 0.31 & 0.81 & 0.65 \\
4 & 16 & 1.75 & 0.24 & 0.65 & 0.76 \\
5 & 16 & 1.79 & 0.46 & 1.27 & 0.48 \\
6 & 16 & 2.04 & 0.58 & 1.62 & 0.29 \\
\hline
\end{tabular}



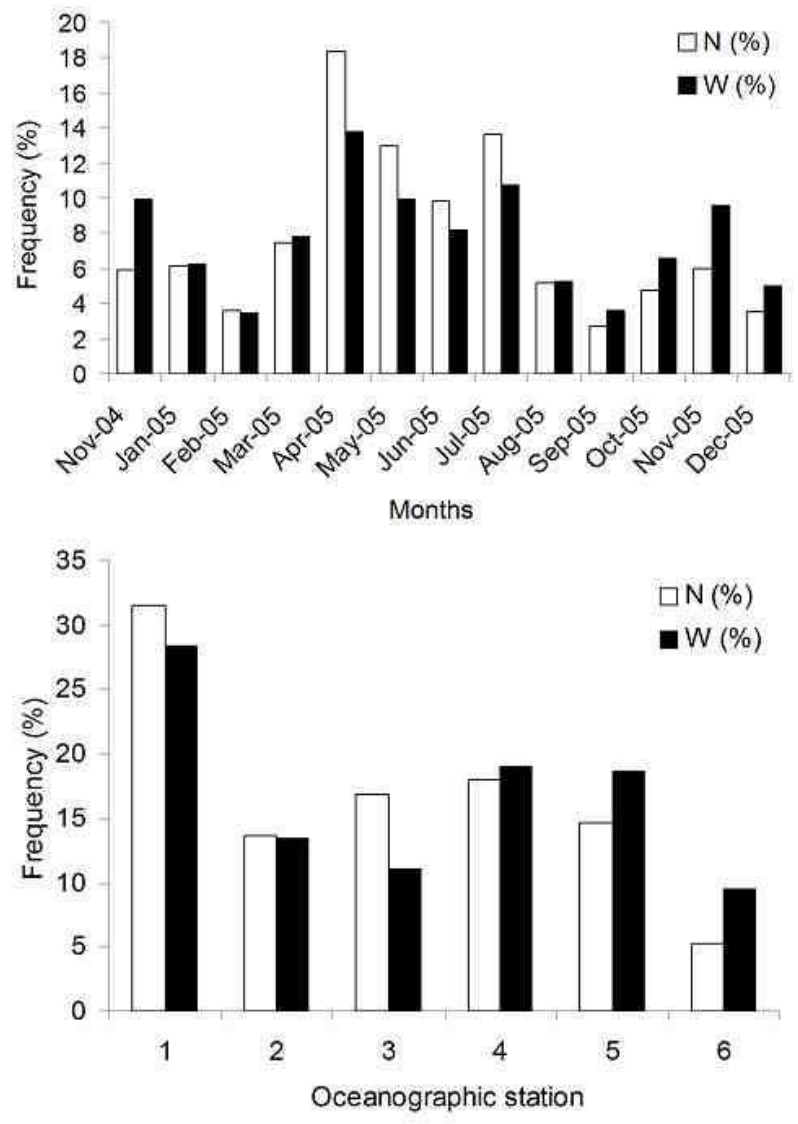

Fig. 4. Frequency of abundance and weight by month and oceanographic station.

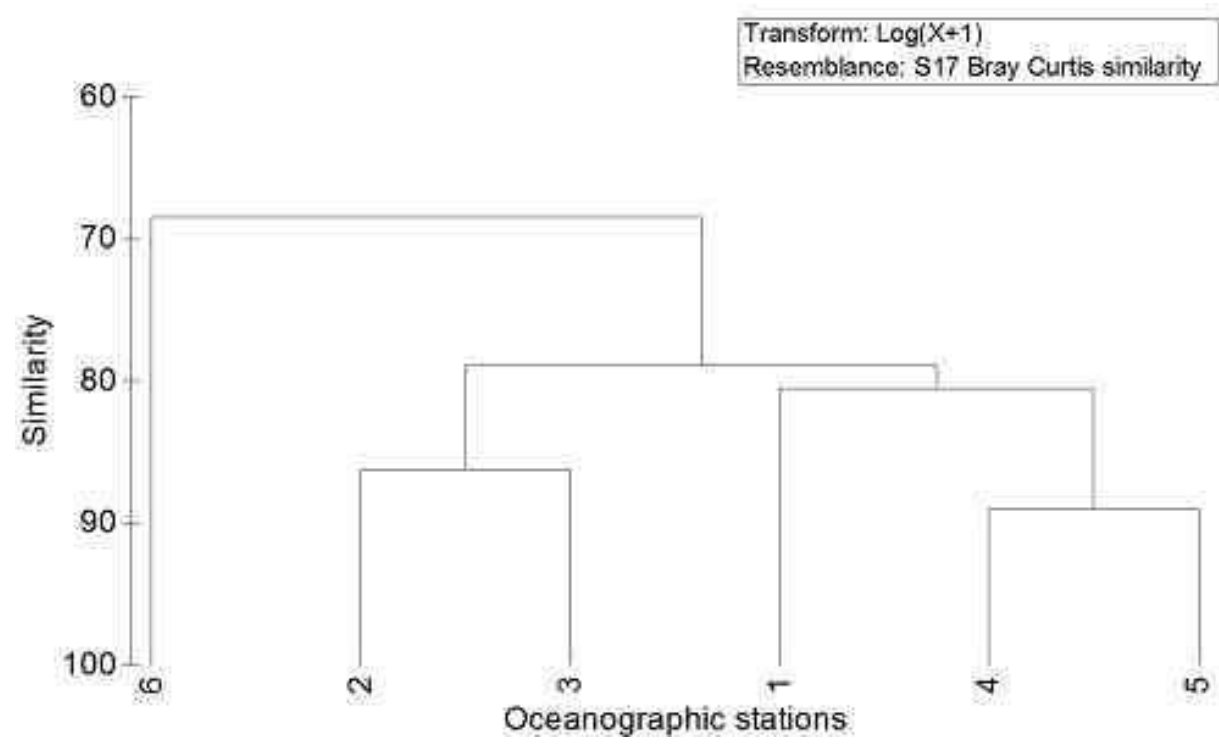

Fig. 5. Clustering analysis of the oceanographic stations in Santos bay, based on species abundance of the Sciaenidae. 


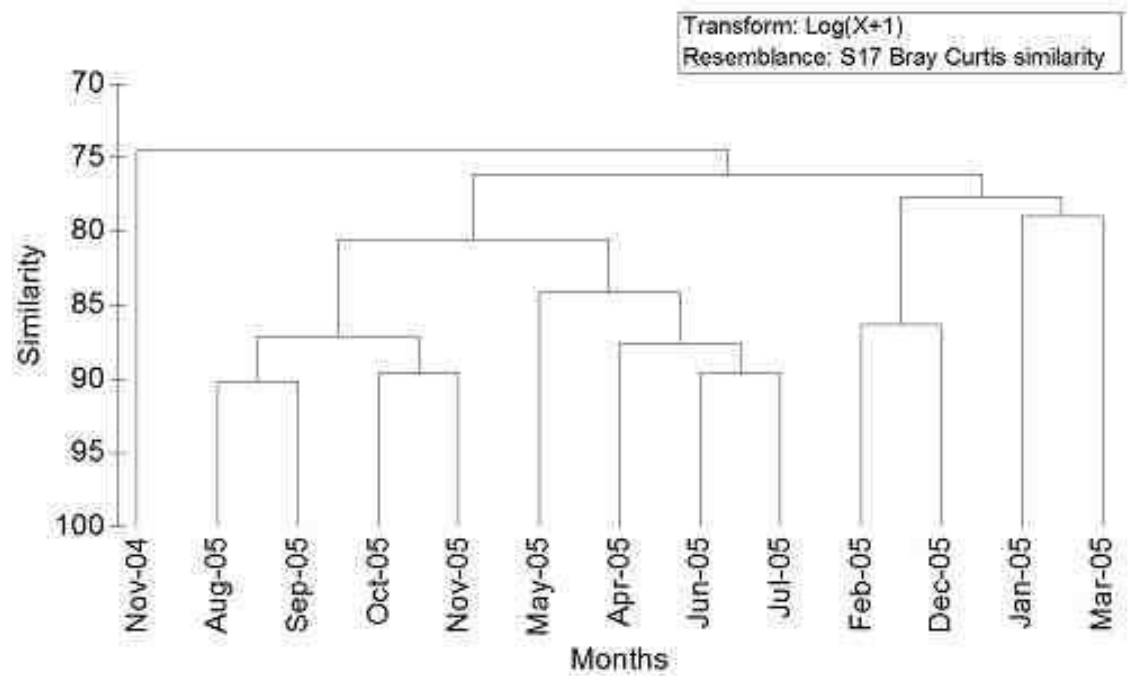

Fig. 6. Clustering analysis of the survey periods in the Santos Bay region, based on species abundance of Sciaenidae.

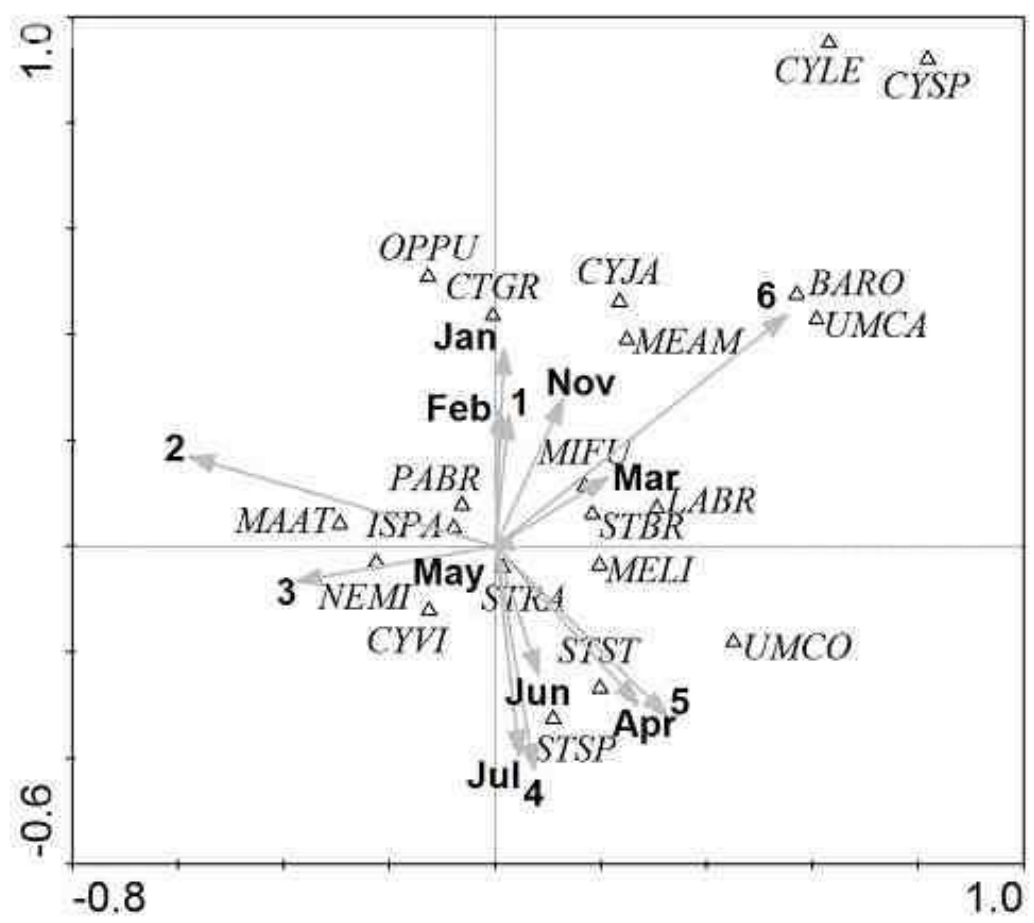

Fig. 7. Canonical correspondence analysis (CCA) between the Sciaenidae species and the spatial and temporal distribution in Santos bay. Species codes are given in table 2. 


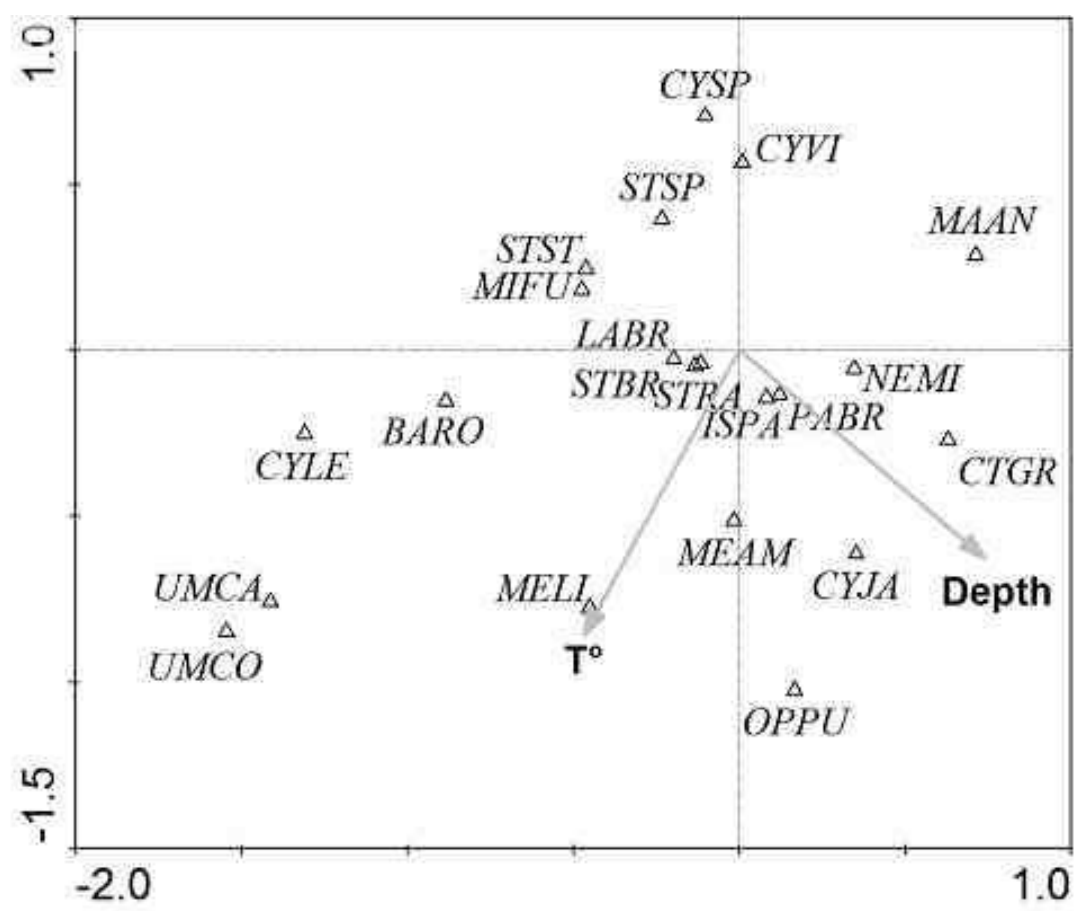

Fig. 8. Canonical correspondence analysis (CCA) between the Sciaenidae species and the environmental variables (temperature and depth). Species codes are given in table 2.

\section{Discussion}

Fish assemblages are potentially impacted by many anthropogenic influences, in such aspects as diversity, distribution, abundance, growth, survival, breeding and food resources (WHITFIELD; ELLIOTT, 2002). Application of fish species richness and diversity in fish assemblage studies can directly assist in the evaluation of the importance and condition of a system (WHITFIELD; ELLIOTT, 2002) - as well as providing important information on the conservation and management of fishery resources in degraded ecosystems (MELO, 2008). It is, however, difficult to compare the species richness and abundance of different areas, because the habitats are different and fishery effort may also differ (ARAÚJO et al., 2006).

The high representation of Sciaenidae, both in richness, abundance and biomass in fish community studies has been well documented (ARAÚJO et al.,1997; ARAÚJO et al.,1998; CHAVES; CORRÊA, 1998; CHAVES; BOUCHEREAU, 2000; PESSANHA et al., 2000; CASTRO, 2001; ARAÚJO et al., 2002; RAZ-GUZMAN; HUIDOBRO, 2002; GODEFROID et al., 2004; QUEIRÓZ et al.,2006; SCHWARZ JR et al., 2006; SCHWARZ JR. et al., 2007; CARVALHO-NETA; CASTRO, 2008; AZEVEDO et al., 2007; ROCHA et al., 2010). This predominance may be attributed mainly to the fact that the Sciaenid species occur mainly in the demersal strata of the coastal environment (COELHO et al., 1986; GIANNINI; PAIVA FILHO, 1990), thus, a survey based on trawling close to the bottom will have a high representation of Sciaenid in the samples. According to Paiva Filho and Schmiegelow (1986), this family shows the highest number of individuals and biomass in Santos bay, including the adjacent areas. In the same area, Giannini and Paiva Filho (1990) recorded 20 species, with Stellifer rastrifer, Isopisthus parvipinnis, Paralonchurus brasiliensis, Micropogonias furnieri, Stellifer brasiliensis and Menticirrhus americanus, totaling $90 \%$ of the catch, $S$. rastrifer being the species with the highest dominance and abundance. The same abundance pattern was observed in this study with 21 species caught and Stellifer rastrifer accounting for $70 \%$ of the total abundance.

Over the years, some changes regarding species abundance, such as a decrease in the number of individuals of $M$. furnieri and an increase in the abundance of Stellifer brasiliensis, Macrodon atricauda, S. stellifer and Nebris microps (GIANNINI; PAIVA FILHO, 1990; this study), have been recorded. According to Giannini and Paiva Filho (1990), sciaenid species, particularly $S$. rastrifer, $I$. parvipinnis, P. brasiliensis and S. brasiliensis, occur 
mostly in the demersal part of Santos bay. The species Micropogonias furnieri and Menticirrhus americanus, however, are found in a wider range of habitats, as demonstrated by their high abundance in the beach trawl.

The spatial distribution of fish assemblages may provide a useful tool for assessing the level of marine influence on lagoon ecosystems (MARIANI, 2001). The Santos bay fish community presents the highest number of species on the east side, especially for the sciaenid Paralonchurus brasiliensis, Stellifer rastrifer and $S$. brasiliensis (GIANNINI; PAIVA FILHO, 1990). The results of Giannini and Paiva Filho (1990) are consistent with those of this present study, i.e., the highest species richness and diversity occurred in the outer part of Santos bay, and the highest abundance and biomass at station 1 (station located on the east side of Santos bay, next to the Santos Channel), as well as the numerical predominance of the species Stellifer rastrifer, Stellifer brasiliensis and Paralonchurus brasiliensis.

Clear spatial segregation of Sciaenid species has also been reported by other studies. Differences in spatial distribution of sciaenids in the Pinheiros bay (PR) were reported by Schwarz Jr et al (2007). In that study Isopisthus parvipinnis, Stellifer rastrifer and S. brasiliensis showed a preference for the outer part of the bay where marine/oceanic influence was greatest. Similarly Araújo et al. (2006) noted a clear spatial segregation among sciaenid species in the Sepetiba bay (RJ), where Micropogonias furnieri occurred mainly in the inner part of the bay, while Menticirrhus americanus was distributed throughout the bay, and Ctenosciaena gracilicirrhus and Cynoscion leiarchus were most abundant in the outer zone.

Fish assemblages may be considered to be greatly influenced by environmental factors, which affect the available habitat. Depending on individual species' environmental and physiological tolerances, the assemblage may also be influenced by other variables, such as predator-prey interactions and inter and intra-specific competition (WHITFIELD; ELLIOTT, 2002). Further, the type of substrate may influence the distribution of sciaenid species (ARAÚJO et al., 2006), due to availability of prey species, which live in close association with the bottom. For example, a substrate composed of fine sediment may provide support for the settlement of shrimp, which may provide food for sciaenid species (SOUZA et al., 2008). The sediment of Santos bay is composed of sand, except for the areas next to sewage outfalls and the Santos Channel which is composed of salt, silt and clay (MEDEIROS; BÍCEGO, 2004), thus accounting for the occurrence of sciaenid species in these areas.

Other environmental factors can also influence the structure of fish assemblages in bays
(ANSARI et al., 2003). Temperature and salinity fluctuations appear to influence different aspects of the community, with temperature proving to be the best predictor of total abundance, while salinity influences the species richness and total biomass (MARSHALL; ELLIOTT, 1998). Distribution of sciaenid assemblages have also been influenced by other environmental factors. Muto et al. (2000) affirmed that, on the inner shelf of Southeastern Brazil, where the dominant species were Ctenosciaena gracilicirrhus, Paralonchurus brasiliensis and Cynoscion jamaicensis, temperature was the most important variable to explain fish distribution, whereas, according to Giannini and Paiva Filho (1990, 1994), the spatio-temporal distributions of sciaenid species assemblages in Santos bay were influenced by temperature as well as by salinity and oxygen concentration. In this present study, only depth and temperature were found to be related to species distribution. Temperature appeared to influence the distribution of Menticirrhus americanus, but only two individuals were caught between January and April 2005, when the average temperature was $25^{\circ} \mathrm{C}$.

According to Araújo et al. (2006), in Sepetiba Bay (RJ), depth, followed by transparency, were the main environmental variables to influence the distribution of Micropogonias furnieri, Menticirrhus americanus, Ctenosciaena gracilicirrhus and Cynoscion leiarchus. In Pinheiros Bay (PR), depth was the parameter that was observed to exercise a great influence on the abundance of I. parvipinnis and $S$. rastrifer, because these species occurred at great depths (SCHWARZ JR et al., 2007).

In conclusion, this study has shown that the number of species and abundance of Sciaenid have remained high in Santos bay and that their assemblage is dominated by Stellifer rastrifer, as was already the case in the 1990's (GIANNINI; PAIVA FILHO, 1990), that is to say the Sciaenid assemblage has been stable for more than 20 years. The highest species richness and diversity occurred near the Santos Channel, while for the one year for which data were available species richness/diversity was greatest in January. The main environmental factor that has been shown to influence the sciaenid species assemblages was temperature (GIANNINI PAIVA FILHO, 1990; this study). The influence of temperature on the fish assemblage may be a relevant tool in future monitoring of the impact of climate change on fish assemblages. Further work which may take into account differences between years, as well as within years, is required to improve our understanding of the habitats use by sciaenid species and to assess any alterations caused by the impact of anthropogenic effects, whether in the habitats or in the fish assemblages themselves. 


\section{ACKNOWLEGMENTS}

The present study is part of a broader project, inserted in "The Influence of the estuarine complex of Baixada Santista on the ecosystem of the adjacent platform"- ECOSAN, supported by FAPESP (Proc. No 2003/09932-1). The authors wish to thank the crew of the RVs Albacora and Veliger II and the trainees of the Laboratory of reproductive ecology and recruitment of marine organisms for helping in the laboratory analysis.

\section{REFERENCES}

ANSARI, Z. A.; SCEEPADA, R. A.; DALAL, S. G.; INGOLE, B. S.; CHATTERJI, A. Environmental influences on the trawl catches in a bay-estuarine system of Goa, west coast of India. Estuar. coast. Shelf Sci.,v. 56, p. 503-515, 2003.

ARAÚJO, F. G.; CRUZ-FILHO, A. G.; AZEVEDO, M. C. C.; SANTOS, A. C. A.; FERNANDES, L. A. M. Estrutura da comunidade de peixes jovens da margem continental da baía de Sepetiba, RJ. Acta Biol. Leopold. v. 19, p. 61-83. 1997.

ARAÚJO, F. G.; CRUZ-FILHO, A. G.; AZEVEDO, M. C. C.; SANTOS, A. C. A. Estrutura da comunidade de peixes demersais da baía de Sepetiba, RJ. Rev. Brasil. Biol., v. 58, p. 417-430, 1998.

ARAÚJO, F. G.; AZEVEDO, M. C. C.; SILVA, M. A.; PESSANHA, A. L. M., GOMES, I. D.; CRUZ-FILHO, A. G. Environmental influences on the demersal fish assemblages in the Sepetiba Bay, Brazil. Estuaries, v. 25, p. 441-450, 2002.

ARAÚJO, F. G.; GUIMARÃES, F. J. C.; COSTA, M. R. Environmental influences on distribution of four Sciaenidae species (Actinopterygii, Perciformes) in a tropical bay at Southeastern Brazil. Revta bras. Zool., v.23, p. 497-508, 2006.

AZEVEDO, M. C. C.; ARAÚJO, F. G.; CRUZ-FILHO, A G.; PESSANHA, A. L. M.; SILVA, M. A.; GUEDES, A. P. P. Demersal fishes in a tropical bay in southeastern Brazil: Partitioning the spatial, temporal and environmental components of ecological variation. Estuar. coast. Shelf Sci., v. 75, p. 468-480, 2007.

BAIL, G. C.; BRANCO, J. O. Ocorrência, abundância e diversidade da ictiofauna na pesca do camarão setebarbas, na região de Penha, SC. Notas Téc. Facimar, v. 7, p. 73-82, 2003.

BARLETTA, M.; AMARAL, C. S.; CORRÊA, M. F. M.; GUEBERT, F.; DANTAS, D. V.; LORENZI, L.; SAINT-PAUL, U. Factors affecting seasonal variations in demersal fish assemblages at an ecocline in a tropicalsubtropical estuary. J. fish biol., v. 73, p. 1314- 1336, 2008.

BEGON, M.; TOWNSEND, C. R.; HARPER, J. L. Ecology: from individuals to ecosystems. 4 ed. Oxford: Blackwell Publishing, 2006. $738 \mathrm{p}$.

BLABER, S. J. M.; BLABER, T. G. Factors affecting the distribution of juvenile estuarine and inshore fish. J. fish biol., v. 17, p. $143-162,1980$.
BRAGA, E. S.; BONETTI, C. V. D. H.; BURONE, L.; BONETTI FILHO, J. Eutrophication and bacterial pollution caused by industrial and domestic wastes at the Baixada Santista estuarine System - Brazil. Mar. Pollut. Bull., v.40, p. 165 - 173, 2000.

BRANCO, J. O.; VERANI, J. R. Pesca do camarão setebarbas e sua fauna acompanhante, na Armação do Itapocoroy, Penha, SC. In: BRANCO, J. O.; MARENZI, A. W. C. (Org.). Bases ecológicas para um desenvolvimento sustentável: estudos de casos em Penha, SC. Itajaí, SC: Editora da UNIVALI, 2006. p. 153 $-170$.

CARVALHO-FILHO, A.; SANTOS, S.; SAMPAIO, I. Macrodon atricauda (Günther, 1880) (Perciformes: Sciaenidae), a valid species from southwestern Atlantic, with comments on its conservation. Zootaxa, v. 2519, p. 48-58, 2010.

CARVALHO-NETA, R. N. F.; CASTRO, A. C. L. Diversidade das assembléias de peixes estuarinos da Ilha dos Caranguejos, Maranhão. Arq. Ciênc. mar, v. 41, p. 48-57, 2008.

CASTRO, A. C. L. Diversidade da assembléia de peixes em igarapés do estuário do Rio Paciência (MA - Brasil). Attântica, Rio Grande, v. 23, p. 39-46, 2001.

CETESB (Companhia Ambiental do Estado de São Paulo). Sistema estuarino de Santos e São Vicente. São Paulo: Relatório técnico, 2001. 183p.

CHAO, N. L. Sciaenidae. In: The living marine resources of the Western Central Atlantic. v. 3: Bony fishes, Part 2 (Opistognathidae to Molidae), sea turtles and marine mammals. FAO species identification guide for fishery purposes and American Society of Ichthyologist and Herpetologists Special Publication n ${ }^{\circ} 5$. Western Central Atlantic. v. 3. Rome: Food and Agriculture Organization, 2002. p. $1583-1653$.

CHAVES, P. T. C.; CÔRREA, M. F. M. Composição ictiofaunística da área de manguezal da baía de Guaratuba, Paraná, Brasil. Revta bras. Zool., v.15, p. 195-202, 1998.

CHAVES, P.; BOUCHEREAU, J. L. Use of mangrove habitat for reproductive activity by the fish assemblage in the Guaratuba Bay, Brazil. Oceanol. Acta, v.23, p. 273-280, 2000.

COELHO, J. A. P.; PUZZI, A. GRAÇA LOPES, R.; RODRIGUES, E. S.; PRIETO JR., O. Análise da rejeição de peixes na pesca artesanal dirigida ao camarão sete-barbas (Xiphopenaeus kroyeri) no litoral do estado de São Paulo. Bolm Inst. Pesca, S Paulo, v. 13, p. 4254, 1986.

GIANNINI, R.; PAIVA FILHO, A. M. Os Sciaenidae (Teleostei: Perciformes) da baía de Santos (SP), Brasil. Bolm Inst. Oceanogr., S Paulo, v. 38, p. 69-86, 1990.

GIANNINI, R.; PAIVA FILHO, A. M. Aspectos biológicos de Isopisthus parvipinnis (Perciformes, Sciaenidae) na Baía de Santos, SP, Brasil. Rev. Brasil. Biol., v. 54, p. 135-145, 1994.

GODEFROID, R. S.; SPACH, H. S.; SANTOS, C.; MACLAREN. G.; SCHWARZ JR, R. Mudanças temporais na abundância e diversidade da fauna de peixes do infralitoral raso de uma praia, sul do Brasil. Iheringia, ser. Zool., v. 94, p. 95-104, 2004.

GOMES, I. D.; CHAVES, P. T. Ictiofauna integrante da pesca de arrasto camaroeiro no litoral sul do estado do Paraná, Brasil. Bioikos, v. 20, p. 9-13, 2006. 
GRACA-LOPES, R.; TOMÁS, A. R. G.; TUTUI, S. L. S.; SEVERINO RODRIGUES, E.; PUZZI, A. Fauna acompanhante da pesca camaroeira no litoral do estado de São Paulo, Brasil. Bolm Inst. Pesca, S Paulo, v. 28, p. 173-188, 2002.

MARIANI, S. Can spatial distribution of ichthyofauna describe marine influence on Coastal Lagoons? A central Mediterranean Case study. Estuar. coast. Shelf Sci., v.52, p. 261-267, 2001.

MARSHALL, S.; ELLIOTT, M. Environmental influence on the fish assemblage of the Humber estuary, U. K. Estuar. coast. Shelf sci., v. 46, p. 175 - 184, 1998.

MEDEIROS, P. M.; BÍCEGO, M. C. Investigation of natural and anthropogenic hydrocarbon inputs in sediments using geochemical markers. I. Santos, SP - Brazil. Mar. Pollut. Bull., v. 46, p. 761 - 769, 2004.

MEIRA, P. T. F.; GRAÇA-LOPES, R. da; PITA, J. B.; SEVERINO RODRIGUES, E. Observações bioecológicas sobre o complexo baía-estuário de Santos. In: SEMINÁRIO SÍNTESE DO CONHECIMENTO SOBRE A BAIXADA SANTISTA, 1983, São Paulo: CETESB, v. 1, p. 116-122.

MELO, A. S. O que ganhamos "confundindo" riqueza de espécies e equabilidade em um índice de diversidade? Biota Neotrop., v. 8, p. $21-27,2008$.

MENEZES, N. A.; FIGUEIREDO, J. L. Manual de peixes marinhos do sudeste do Brasil. IV. Teleostei (3). São Paulo: Museu de Zoologia - Universidade de São Paulo, 1980. 96p.

MENEZES, N. A.; BUCKUP, P. A., FIGUEIREDO, J. L.; MOURA, R. L. Catálogo das espécies de peixes marinhos do Brasil. São Paulo: Museu de Zoologia Universidade de São Paulo, 2003. 160p.

MUTO, E. Y.; SOARES, L. S. H.; ROSSIWONGSTSCHOWSKI, C. L. D. B. Demersal fish assemblage off São Sebastião, southeastern Brazil: structure and environmental conditioning factors (summer 1994). Revta bras. Oceanogr., v. 48, p. 9-27, 2000.

NELSON, J. S. Fishes of the world. 4 ed. New Jersey: John Wiley \& Sons, 2006. 601p.

PAIVA FILHO, A. M.; SCHMIEGELOW, J. M. M. Estudo sobre a ictiofauna acompanhante da pesca do camarão sete-barbas, Xyphopenaeus kroyeri, nas proximidades da Baía de Santos, SP. Bolm. Inst. Oceanogr., v. 34, p. 7985, 1986.

PESSANHA, A. L. M.; ARAÚJO, F. G.; AZEVEDO, M. C. C.; GOMES, I. D. Variações temporais e espaciais na composição e estrutura da comunidade de peixes jovens da baía de Sepetiba, Rio de Janeiro. Revta bras. Zool., v. 17, p. $251-261,2000$
QUEIROZ, G. M. L. N.; SPACH, H. L.; SOBOLEWSKIMORCELOS, M.; SANTOS, L. O.; SCHWARZ JR, R. Caracterização da ictiofauna demersal de duas áreas do complexo estuarino de Paranaguá, Paraná, Brasil. Biociências, v. 14, p. 112-124, 2006.

RAZ-GUZMAN, A.; HUIDOBRO, L. Fish communities in two environmentally different estuarine systems of Mexico. J. Fish Biol., v. 61 (supplement A), p. 182195,2002.

ROCHA, M. L. C. F.; FERNANDEZ, W. S.; PAIVA FILHO, A. M. Spatial and temporal distribution of fish in Palmas Bay, Ubatuba, Brazil. Braz. J. Oceanogr., v. 58, p. 3143, 2010.

SANTOS, M. C. F.; FREITAS, A. E. T. S.; SILVA, M. M. Composição da ictiofauna acompanhante da pesca de camarão em Tamandaré/PE e Pontal do Pebal/AL. Bol. Téc. Cient. CEPENE, v. 6, p. 1-18, 1998.

SCHWARZ JR, R.; FRANCO, A. C. N. P.; SPACH, H. L.; SARPEDONTI, V.; PICHLER, H. A.; NOGUEIRA DE QUEIROZ, G. M. L. Composição e estrutura da ictiofauna demersal na baía dos Pinheiros, Paraná. Braz. J. Aquat. Sci. Technol., v. 10, p. 27-39, 2006.

SCHWARZ JR, R.; FRANCO, A. C. N. P.; SPACH, H. L.; SANTOS, C.; PICHLER, H. A.; QUEIROZ, G. M. L. N. Variação da estrutura espacial da ictiofauna demersal capturada com rede de arrasto de porta na baía dos Pinheiros, PR. Bolm Inst. Pesca, v. 33, p. 157-169, 2007.

SOSA-LÓPEZ, A.; MOUILLOT, D. RAMOS-MIRANDA, J.; FLORES-HERNANDEZ, D.; CHI, T. D. Fish species richness decreases with salinity in tropical coastal lagoons. J. Biogeogr., v. 34, p. 52-61, 2007.

SOUZA U. P.; COSTA R. C.; MARTINS I. A.; FRANSOZO A. Associações entre as biomassas de peixes Sciaenidae (Teleostei: Perciformes) e de camarões Penaeoidea (Decapoda: Dendrobranchiata) no litoral norte do Estado de São Paulo. Biota Neotrop., v. 8, p. 21-30, 2008.

VIANNA, M.; COSTA, F. E. S.; FERREIRA, C. N. Lengthweight relationship of fish caught as by-catch by shrimp fishery in the Southeastern coast of Brazil. Bolm Inst. Pesca, São Paulo, v. 30, p. 81-85, 2004.

WHITFIELD, A. K.; ELLIOTT, M. Fishes as indicators of environmental and ecological changes within estuaries: a review of progress and some suggestions for the future. J. Fish. Biol., v. 61, p. 229-250, 2002.

(Manuscript received 06 October 2011; revised 20 December 2011; accepted 05 March 2012) 